\title{
Territorial approach to increased energy consumption of water extraction from depletion of a highlands Mexican aquifer
}

\author{
Carlos Roberto Fonseca*, María Vicenta Esteller ${ }^{1}$, Carlos Díaz-Delgado ${ }^{2}$ \\ Centro Interamericano de Recursos del Agua, Facultad de Ingeniería, Universidad Autónoma del Estado de México, Cerro de Coatepec,
} Ciudad Universitaria s/n, CP 50110 Toluca, Estado de México, Mexico

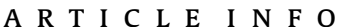

\section{Article history:}

Received 18 September 2012

Received in revised form

17 June 2013

Accepted 24 June 2013

Available online

\section{Keywords:}

Groundwater pumping

Energy consumption isopleths

Groundwater level drawdown

Groundwater pumping costs

\begin{abstract}
A B S T R A C T
This work proposes a method to estimate increased energy consumption of pumping caused by a drawdown of groundwater level and the equivalent energy consumption of the motor-pump system in an aquifer under intensive exploitation. This method has been applied to the Valley of Toluca aquifer, located in the Mexican highlands, whose intensive exploitation is reflected in a decline in the groundwater level of between 0.10 and $1.6 \mathrm{~m} /$ year. Results provide a summary of energy consumption and a map of energy consumption isopleths showing the areas that are most susceptible to increases in energy consumption due to pumping.

The proposed method can be used to estimate the effect of the intensive exploitation of the Valley of Toluca aquifer on the energy consumption of groundwater extraction. Finding reveals that, for the year 2006, groundwater extraction in the urban zone required 2.39 times more energy than the conditions observed 38 years earlier. In monetary terms, this reflects an increase of USD\$ 3 million annually, according to 2005 energy production costs.
\end{abstract}

(c) 2013 Elsevier Ltd. All rights reserved.

\section{Introduction}

Intensive groundwater exploitation generally triggers a series of negative environmental and socioeconomic effects (Changming et al., 2001; Esteller and Diaz-Delgado, 2002). Among these are the drawdown of groundwater level and its corresponding economic impact due to the increased cost of pumping from greater depths and affects on activities that depend on groundwater (Harou and Lund, 2008; Kajenthira et al., 2012; Martin and van de Giesen, 2005; Salameh, 2008). For example, in irrigation areas, the excessive drawdown of groundwater level can direct impacts changes to irrigation systems, such as result of the increased energy costs due to pumping from greater depths, as well as increased pumping time and decreased pumping efficiency. Cost increases occur because of changes that be done place in well installations for maintaining the same efficiency and production (Ramos and Ramos, 2009; Venot and Molle, 2008; Zacharias et al., 2003).

\footnotetext{
* Corresponding author. Tel.: +52 72229655 50x129.

E-mail addresses: crfonsecao@uaemex.mx, car.fon.or@live.com.mx (C.R. Fonseca), mvestellera@uaemex.mx (M.V. Esteller), cdiazd@uaemex.mx (C. Díaz-Delgado).

1 Tel: +52 $7222965550 \times 108$.

2 Tel.: +52 72229655 50x104.
}

Nevertheless, water managers more often concern with water shortages, supply intensification and management and, to some extent, water pollution. They rarely give attention to energy requirements, even though water and energy policies are closely related (Biswas, 2004; MacDonald et al., 2009; Malik, 2002).

Estimating pumping costs is a significant part of any study related to aquifer remediation or groundwater management models. For example, in a modeling study for the optimal management of an aquifer, Hsiao and Chang (2002) considered both time variations for flow pumping and the total cost, including installation (fixed) and pumping (operations) costs. Study showed the affect of installation costs on the determination of the number of wells and their location. Harou and Lund (2008) used the variable "pumping cost" as part of their hydrologic-economic optimization model to study economic effects and management measures that must be taken when an aquifer is already overexploited. Furthermore, because groundwater pumping may represent the biggest portion of energy consumption in water resources management, authors such as Thi Hoang Duong et al. (2011) use it as a strategies indicator and Scott and Shah (2004) apply it as a tool to manage aquifer depletion.

Although pumping costs can be estimated in monetary units, it is difficult to put a precise value on cost increases resulting from lower piezometric levels (Harou and Lund, 2008; Molina et al., 2009). Estimates only based on monetary units are limited by 
monetary fluctuations, amortizations and subsidies, as well as other economic instruments that can exist at any given moment may hinder the real impact of cost increases due to a groundwater level drawdown. In light of this "business-as-usual" attitude (Biswas, 2004), we propose estimating costs based on an evaluation in energy units (joules) to represent the energy consumption involved in extracting water from greater depths - an assessment that can only be affected by significant technological changes. Also, these units could be appropriate to conduct environmental evaluations whose methods use energy units to identify measure and weigh the relationships in a system.

This work proposes an easy method for using a territorial approach to estimate the energy consumption of pumping groundwater from greater depths until to the land surface (including energy consumption using the motor-pump system) as a consequence of the intensive exploitation of aquifers. Similar to other studies (Hoque et al., 2007; Carrera-Hernadez and Gaskin, 2007), this work uses the piezometric level as an indicator of intensive exploitation and aquifer dewatering, highlighting the importance of monitoring this level to manage groundwater resources. Therefore, the method proposed requires a database that provides spatially-distributed information about piezometric levels and volumes extracted from groundwater.

The results obtained using a territorial approach may be used as a management tool to define potential groundwater extraction zones and the likely direction of urban growth by taking into account the groundwater pattern, as proposed by Sekar and Randhir (2007) and Gupta and Srivastava (2010).

In addition, the study is based on energy units in order to provide the bases for managing the increases in energy consumed to extract water, such as: a) an economic impact in groundwater resources management and b) an externality in terms of an environmental evaluation.

As a case study, we present problems related to the Valley of Toluca aquifer, where the average decline in groundwater levels in urban zones is estimated at $1.4 \mathrm{~m}$ per year from 1968 to 2006 (Esteller et al., 2012), which is caused by groundwater extraction for both local supply and interbasin transfer to the Valley of Mexico (the largest urban population in the country).

\section{Study area}

Mexico is one of the largest users of groundwater in the world and faces challenges related to a critical overdraft and a growing energy demand for groundwater pumping. Examples of this can be seen in the aquifers in the Valley of Mexico (Carrera-Hernández and Gaskin, 2007), Salamanca (Esteller et al., 2011), San Luis Potosí (Esteller et al., 2011; Martínez et al., 2011), Guanajuato (Wester et al., 2009, 2011), Querétaro (Palacios-Vélez et al., 2002) and the Valley of Toluca (Esteller et al., 2011). Generally, for urban uses, electrical energy represents half of the total cost of water supply processes (Loustaunau, 2011). Energy consumption for agricultural water use appears to be stagnating nationally, at about $8000 \mathrm{GWh} /$ year (Scott, 2011). In 2009, this represented about $5 \%$ of the total energy demand. It is supported by public agencies through subsidies and accounts for $26 \%$ of the energy consumed for groundwater extraction (Avila et al., 2005). Since the cost is a main budgetary element in public policies concerning the water supply, it is useful to highlight the importance of including methods and tools (not yet developed or implemented) that will help to reduce the cost of energy consumption and manage the effects of depleting the groundwater level.

The Valley of Toluca is located in the Mexican highlands, with an average altitude of 2570 m.a.s.l. In 2005, the population of Toluca's metropolitan area reached 1.61 million inhabitants (INEGI, 2005), making it the fifth most populated metropolitan area in Mexico. This valley is an important center of industrial (3438 enterprises) and agricultural activity (136 organized irrigation units with a total area of 21,233 ha and 16,724 users) (CONAGUA, 2007).

The Valley of Toluca aquifer is located in the upper course of the Lerma River, and is part of the Lerma-Santiago-Pacifico basin (Fig. 1). Its borders are the Atlacomulco-Ixtlahuaca aquifer to the north, the Tenango Hill to the south, the Nevado de Toluca Volcano to the southwest and the mountains Sierra de las Cruces and Monte Alto to the east; covering a total area of $2767 \mathrm{~km}^{2}$. The mountain ranges located in the high-topography portions were produced by a thick sequence of Oligocene andesite and rhyolite, Miocene andesite, and Quaternary basalt and andesite. At lower altitudes, the basin-fill material is composed of lacustrine and alluvial sediments interbedded with clastic volcanic material (pyroclasts, tuff, and

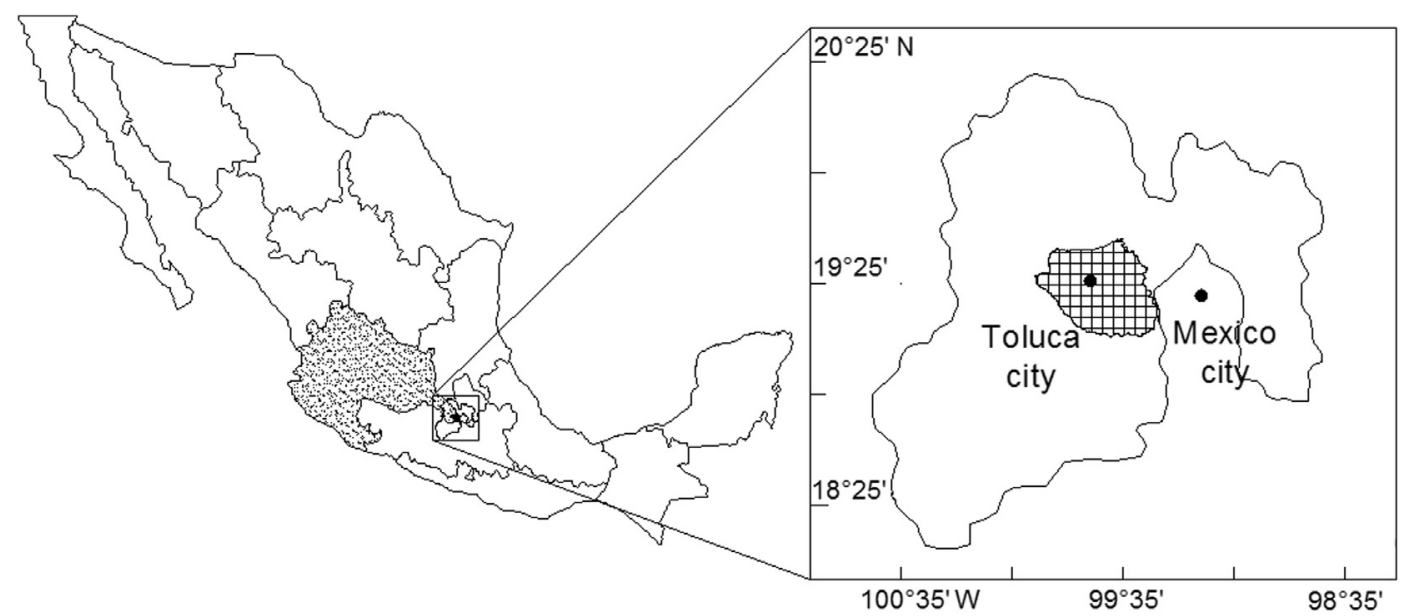

Lerma- Santiago- Pacifico

Basin

State of Mexico

Fig. 1. Location of the study area. Valley of Toluca aquifer (Mexico). Own elaboration. 
breccia) with a composite thickness ranging from a few meters at the boundary with the mountains to more than $500 \mathrm{~m}$ (Herrera and Sanchez, 1994; Esteller et al., 2011). A wide range of hydraulic parameters exist in the Valley of Toluca aquifer due to the lithological and geometric variability of the sediments. Transmissivity values between 90 and $400 \mathrm{~m}^{2} /$ day are found in the central zone and storativity is between 0.3 and $0.9 \%$ (Esteller and Díaz-Delgado, 2002). The drawdown of the groundwater level in the aquifer has been induced by intensive groundwater exploitation to meet the domestic water supply needs of the valley's population, as well as those of a large percentage of Mexico City's population and, to a lesser extent, for use by industrial and agricultural activities (Esteller et al., 2013). This intensive exploitation has become evident by both the dewatering of the largest surface water bodies in the basin (Almoloya lagoons) and a negative water balance, estimated at a deficit of $142 \mathrm{hm}^{3} /$ year ( $513 \mathrm{~m}^{3} /$ ha year), which is covered by the non-renewable groundwater reserve (Mejia, 2003).

Fig. 2 shows groundwater exploitation over time. According to Mejía (2003), the highest extraction growth $\left(20 \mathrm{hm}^{3} /\right.$ year $)$ occurred in the well facilities that supply Mexico City (1940-1950), while the demographic and industrial growth in the region caused an additional rate of growth in extraction of approximately $10 \mathrm{hm}^{3}$ / year (1970-1990).

This study includes 762 extraction wells inventoried in the Valley of Toluca aquifer (Fig. 3). Although it is known that there are more wells, information on the volume of water extracted from them is not available (IMTA, unpublished internal report, 2006). This inventory includes data for annual volumes of water extracted for different uses, as well as the location of the wells in 2006. Based on this database, domestic use represents $83.4 \%$ (395.74 $\mathrm{hm}^{3} /$ year), industrial water use $7.9 \%\left(37.27 \mathrm{hm}^{3} /\right.$ year $)$, agricultural water use $7.3 \%$ (34.5 $\mathrm{hm}^{3} /$ year) and other uses $1.4 \%$ (6.64 $\mathrm{hm}^{3} /$ year).

Seventy-one percent of extraction rates are below $8 \mathrm{Lps}, 24 \%$ are below 28 Lps and only 5\% are as high as 42 Lps. In addition, most (65\%) of the registered wells are between 150 and $300 \mathrm{~m}$ deep, while $26 \%$ are as deep as $450 \mathrm{~m}$ and $8 \%$ are less than $150 \mathrm{~m}$ in depth. Only $1 \%$ of the wells are between 450 and $600 \mathrm{~m}$ deep and their water volume is for industrial use.

It is important to note that the Mexican Republic has piezometric networks in 211 of its 653 aquifers, with a total of 8100 monitoring points (CONAGUA, 2007). These networks provide basic information to determine the behavior of groundwater levels.
The Valley of Toluca aquifer has a piezometric network consisting of 65 piezometers operated by CONAGUA. Based on the data available for groundwater levels, it was possible to estimate supply zones ranging from $3.6 \mathrm{~m}$ in open fields to $61.5 \mathrm{~m}$ in urban zones (Fig. 2), indicating that if the trend of $1.6 \mathrm{~m} / \mathrm{year}$ in the urban zone were to continue, the most of extraction wells with a depth of $150 \mathrm{~m}$ would have a remaining useful life of no more than 40 years from the year 2006 (not including decreases in the dynamic level).

\section{Materials and methods}

The objective of this study is to propose a simple method to determine the energy consumption of groundwater extraction from greater depths and provide strategic information regarding all outputs in order to improve groundwater management. Thus, a method was developed which is presented schematically by the diagram in Fig. 4.

First, the use of groundwater is an activity that affects regions beyond their political limits. Therefore, the ideal delimitation for water resources management is the area that covers an entire aquifer (1). Likewise, information from monitoring groundwater levels (2) makes it possible to estimate the average annual variation in the piezometric level (3) for the periods of time under consideration ( 6 and 7 years for the case study). Also, the initial depth of groundwater (4) is defined according to the oldest piezometric level records in order to generate maps, using a geographic information system (GIS) that provide spatially-distributed piezometric information (5).

Similar to volumes of water extracted, an inventory of extraction wells (6) should contain their locations in the same system of reference as the piezometric information in order to assign to each well its initial extraction depth and the mean annual variations in groundwater level (7). Dynamic levels involving the extraction of water can be used when the corresponding field tests are registered for each well. Otherwise, the static level, which comes from the piezometric monitoring network, provides an estimate of the minimum energy consumption of water extraction. The difference between estimating energy consumption using dynamic versus static levels depends on the nearness of the monitoring points to the extraction wells, as well as the number of wells per unit area.

Two types of results can be obtained based on the consideration of the operational characteristics (such as extraction flow and motor

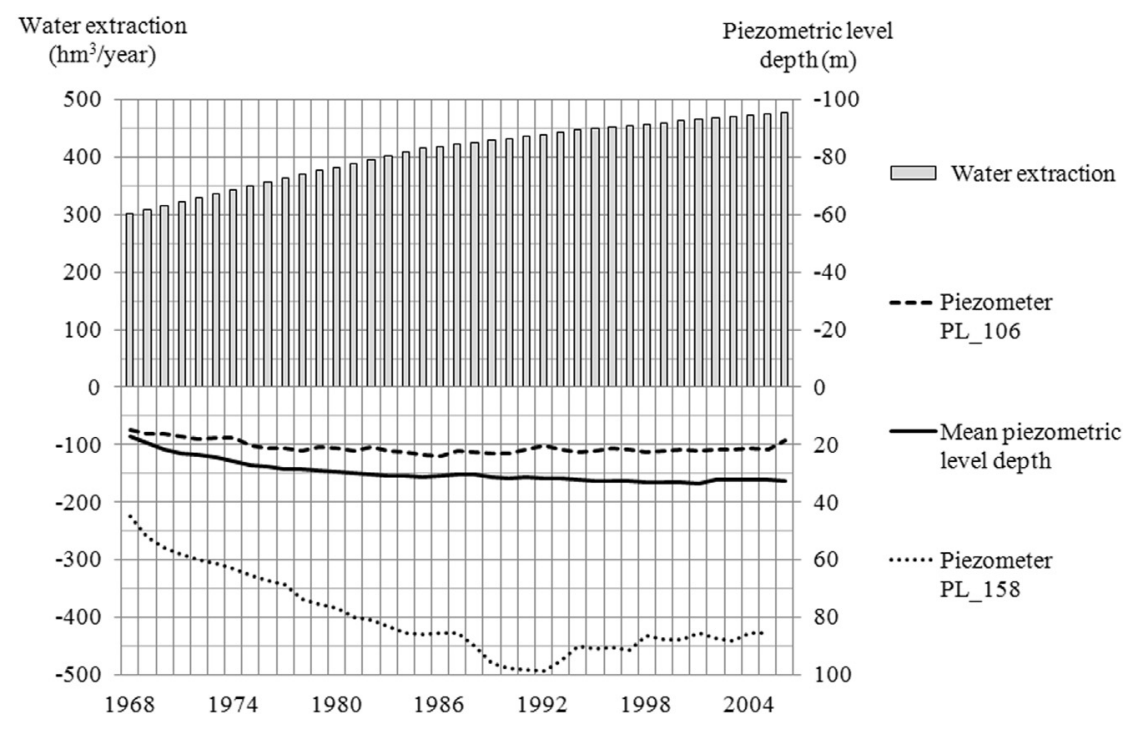

Fig. 2. Volume of extracted water and drawdown of groundwater level over time. Own elaboration. 


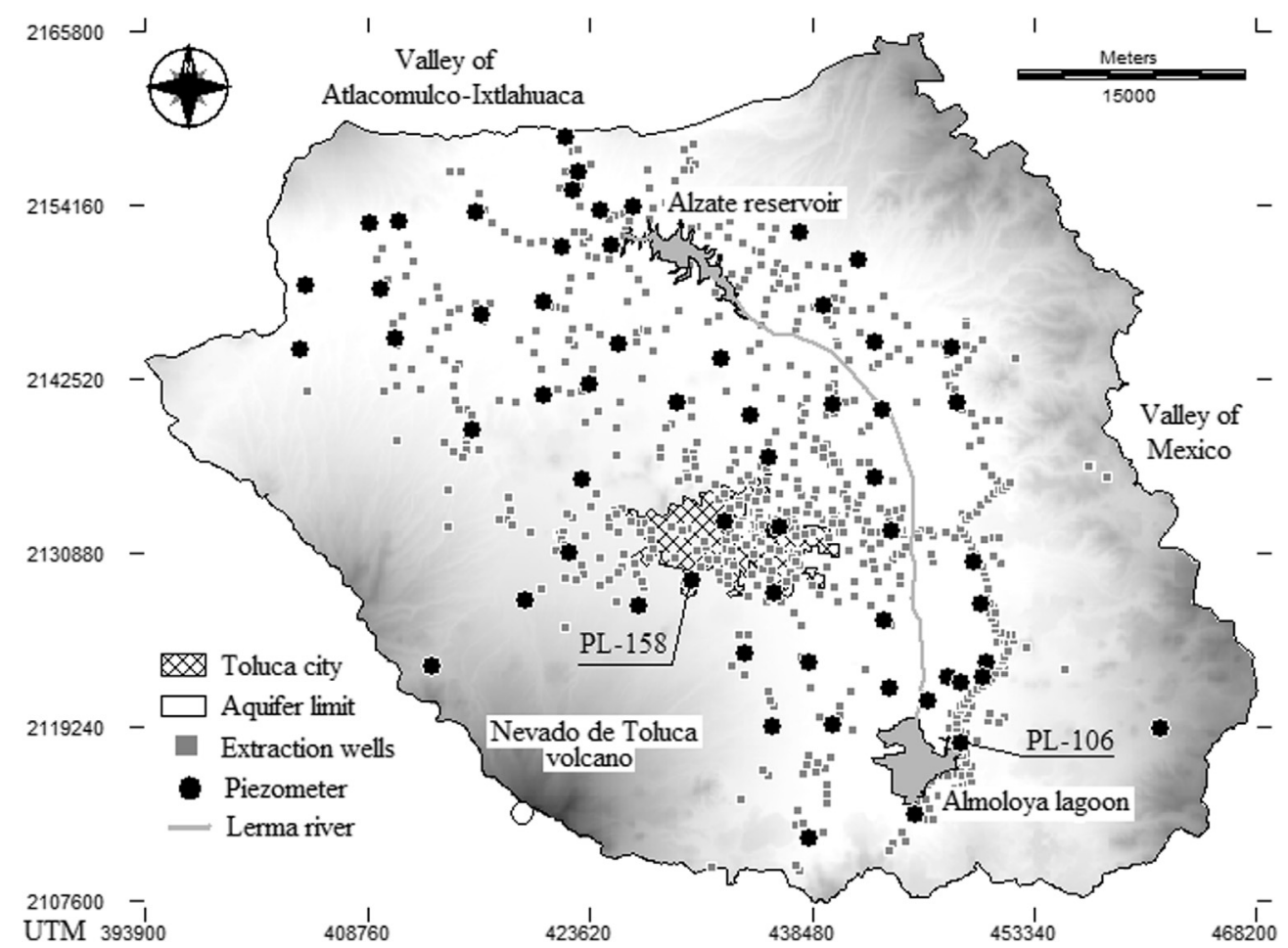

Fig. 3. Piezometer and extraction wells location in the Valley of Toluca aquifer (2006). Own elaboration with data from IMTA (2006).

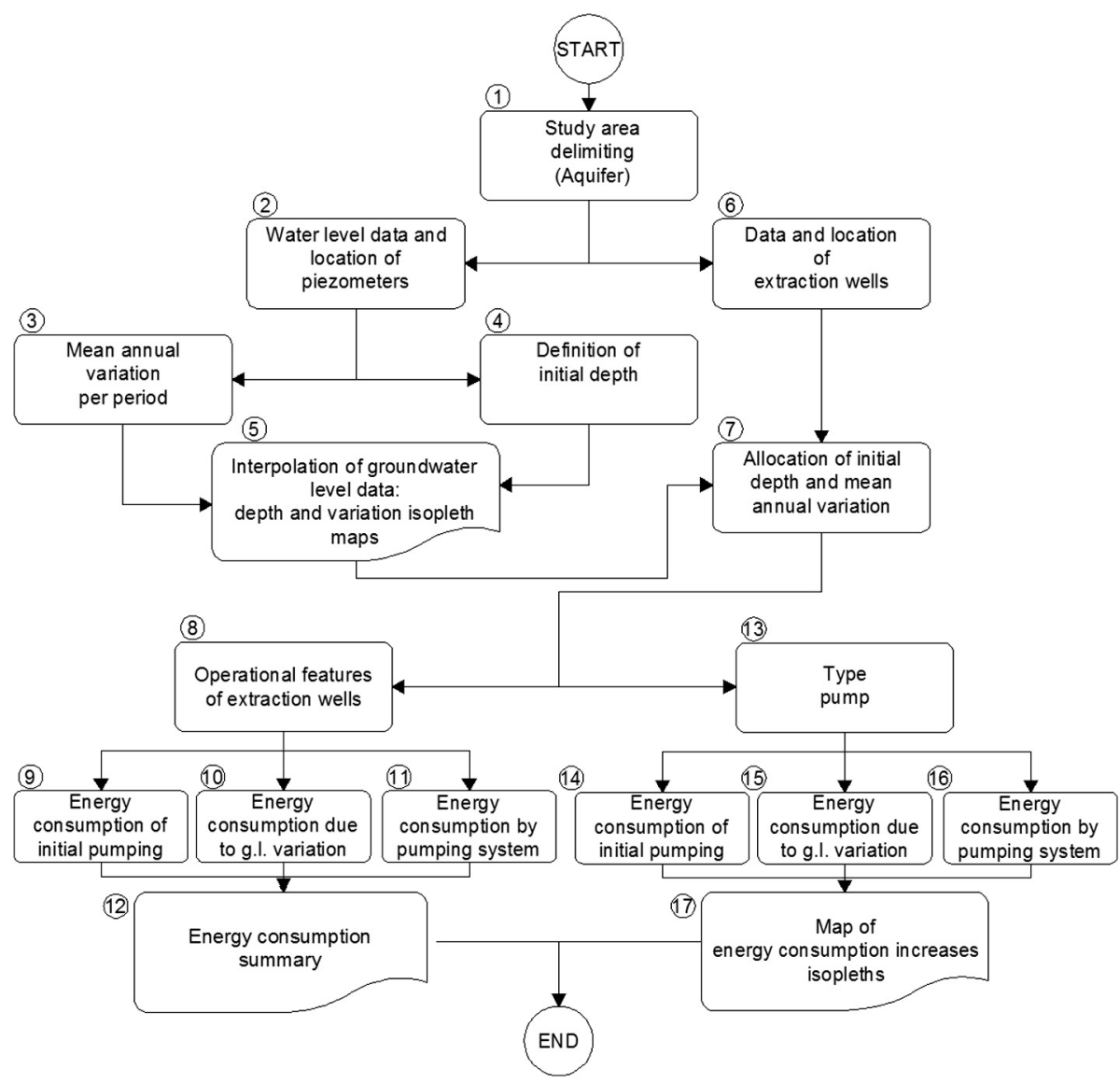

Fig. 4. Flow chart of methodology followed for estimating energy consumption of water extraction. Own elaboration. Note: g.l. = groundwater level. 
power) related to water extraction. First, when information regarding the operational characteristics for each well is available (8), the point estimate and energy consumption summary are obtained for the use of groundwater during a period (12). Second, when using the same operational characteristics for all of the extraction wells (13) - that is, a "type pump"- maps can be generated that identify the areas which are more susceptible to increases in energy consumption due to pumping groundwater (17).

Regardless of the type of results desired, the energy consumption of groundwater extraction must be estimated. The present work considers this energy consumption to have three components: a) the energy consumption of initial pumping operations (9 and 14); b) that due to variations in groundwater levels (10 and 15) and; c) consumption resulting from the use of pumping equipment (11 and 16). The three components are estimated mainly using the equation for the power $P=\gamma Q H \eta^{-1}$ with which a water flow $Q$ $\left(\mathrm{m}^{3} \mathrm{~s}^{-1}\right)$, with a specific weight $\gamma\left(\mathrm{kg} \mathrm{m}^{-3}\right)$, exceeds a hydraulic head $H(\mathrm{~m})$ with an efficiency $\eta$ (MacDonald et al., 2009). In this case, the power can be measured in kilowatts, but in annual terms, it is preferable to use $\mathrm{J} /$ year $\left(1 \mathrm{~kW}=1000 \mathrm{~J} / \mathrm{s}=1000 \mathrm{~kg} \mathrm{~m}^{2} \mathrm{~s}^{-3}\right)$, while the hydraulic head $H$ depends on both the head resulting from the position - that is, the depth of the groundwater - as well as the loss in head in the pumping system.

The energy consumption $C_{\text {iniop }}$ (kJ/year) for the initial operation (9 and 14 in Fig. 4) is defined by Eq. (1),
$C_{\text {iniop }}=31,536 \gamma Q_{0} H_{0} \eta^{-1}$

where the hydraulic head corresponds to the depth $H_{0}(\mathrm{~m})$ of the piezometric level during the first year on record and the mean extracted water $Q_{0}\left(\mathrm{~m}^{3} / \mathrm{s}\right)$ is the water extracted during that year. The term 31,536 is the conversion factor for the power $P$ in units $\left(\mathrm{J} \mathrm{s}^{-1}\right)$ to the annual energy consumption $\left(1 \mathrm{~J} \mathrm{~s}^{-1}=365\right.$ days $\times 24 \mathrm{~h} \times 3600 \mathrm{~s} \times 1 \mathrm{~kJ} \times 1000 \mathrm{~J}^{-1}=31,536 \mathrm{~kJ} /$ year $)$.

After initial groundwater pumping operations, the additional energy consumption $C_{v a r}$ (kJ/year) caused by the variation in the piezometric level can be estimated (Eq. (2)) for a period of $n$ years with a constant extracted flow of $Q_{k}\left(\mathrm{~m}^{3} / \mathrm{s}\right)$. The hydraulic head is then obtained from the product of the annual mean variation $h_{p}(\mathrm{~m} /$ year) in the piezometric level and a factor representing the annual increase in the piezometric level, that is, the sum of integers powers $n(n+1)\left(2^{-1}\right)$ (Spiegel and Liu, 1999; Fonseca et al., 2010).

$C_{\mathrm{var}}=31,536 \gamma \eta^{-1} Q_{k} h_{p} n(n+1)\left(2^{-1}\right)$

On the other hand, hydraulic head losses are included in the energy consumption $C_{s y s}$ of the pumping system (11 and 16 in Fig. 4). This element, defined by Eq. (3), consists of the energy consumption $C_{a c c}(\mathrm{~kJ} /$ year) corresponding to head losses caused by valves and accessories and the energy consumption related to the power $C_{\text {motor }}(\mathrm{kJ} / \mathrm{year}$ ) of the pumping equipment used.

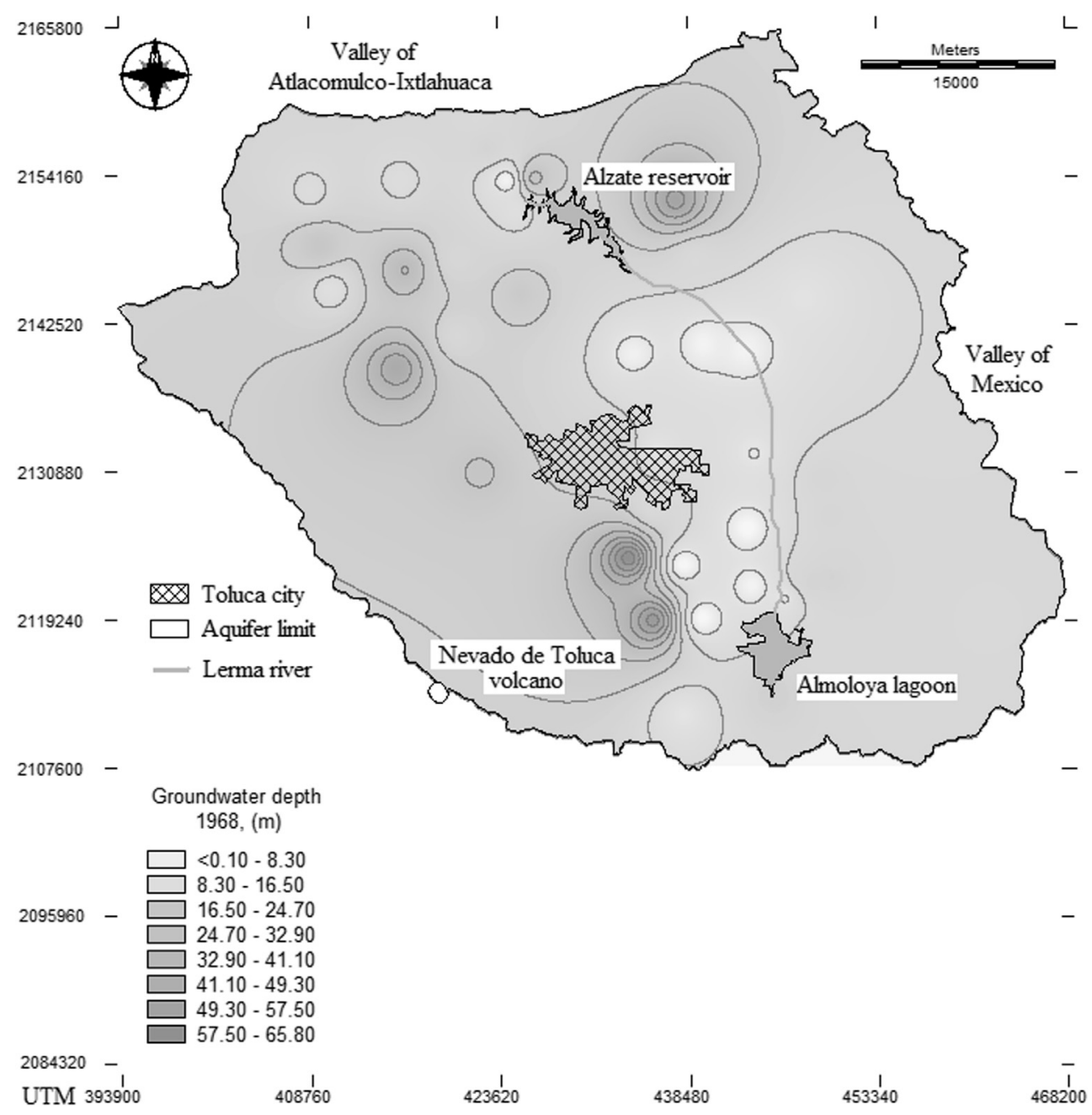

Fig. 5. Map of groundwater depth isopleths of Valley of Toluca aquifer in 1968. Own elaboration. 
$C_{\text {sys }}=C_{a c c}+C_{\text {motor }}$

The energy consumption $C_{a c c}(\mathrm{~kJ} /$ year) caused by head loss due to the friction of fluid flow through the accessories and installed valves is defined by Eq. (4):

$C_{a c c}=31,536 \gamma Q K v^{2}(2 g \eta)^{-1}$

where $v^{2}(2 g)^{-1}$ is the velocity head $(\mathrm{m})$ and $K v^{2}(2 g)^{-1}$ is the general equation for local losses caused by changes in the cross-section geometry or by the presence of valves and sluice gates. Many authors (Kabwe et al., 2010; Yildirim and Singh, 2010) provide values of $K$ for course changes in pipes with a constant diameter and for different kind of valves, i.e. as a function of the pipe diameter. Furthermore, while for flow through an aquifer, the main head has been considered to be the elevation head, the flow that moves vertically by pumping undergoes friction and velocity losses.

To assess the energy consumption corresponding to motor intensity, a factor was determined which considers the relationship between the volume extracted from the pumping well during a specific time period and the potential volume that could be extracted with the nominal power of the motor (Eq. (5)).

$C_{\text {motor }}=31,536 P_{n} Y_{Q}=31,536 P_{n} Q_{\text {extracted }} Q_{\text {nom }}^{-1}$

where $P_{n}$ is the motor's nominal power $(\mathrm{J} / \mathrm{s})$ and $Y_{Q}$ is the yield of the extracted flow, $Q_{\text {extracted }}$ is the volume extracted from the well
( $\mathrm{m}^{3} \mathrm{~s}^{-1}$ ) and $Q_{\text {nom }}$ is the potential volume that can be extracted with the nominal power $\left(\mathrm{m}^{3} \mathrm{~s}^{-1}\right)$.

The nominal flow $\left(Q_{\text {nom }}\right)$ is estimated by calculating the value for the pumping volume $Q$ in the power equation, considering the initial hydraulic head $H_{0}$.

\subsection{Energy consumption summary}

Estimating energy consumption based on the operational characteristics of each extraction well (12 in Fig. 4), it is possible to calculate:

a. Average annual energy consumption per well, $E C_{a v g w}$, dividing the sum of energy consumptions $C_{i n i o p}, C_{v a r}$ and $C_{s y s}$ of all wells by the number of wells.

b. Average annual energy consumption per cubic meter of water extracted, $E C_{a v g}$, dividing the sum of energy consumptions $C_{\text {iniop }}, C_{\text {var }}$ and $C_{\text {sys }}$ by the total annual volume extracted by the pumping wells.

c. Total operational energy consumption due to variations in the groundwater level for each period $\sum C_{\text {var }}$.

d. Annual operational energy consumption due to variations in the

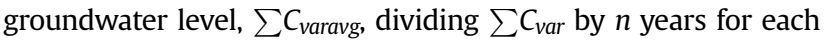
period.

e. Accumulated operational energy consumption due to variations in the groundwater level, ( $\left.\sum C_{\text {varacum }}\right)$, adding the total

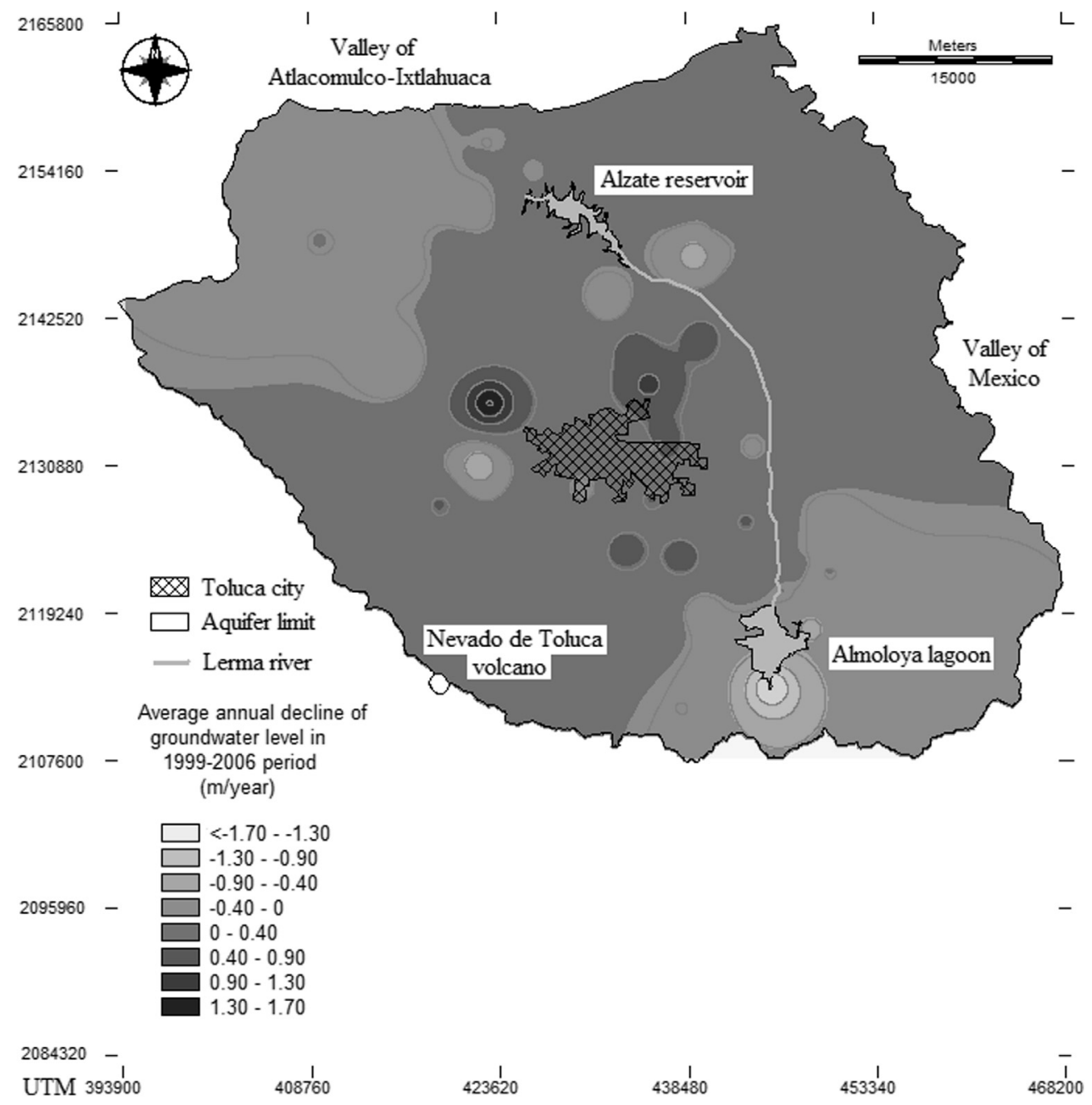

Fig. 6. Map of groundwater drawdown isopleths of Valley of Toluca aquifer in 1999-2006 period. Own elaboration. 
Table 1

Summary of energy consumption by water extraction in the aquifer of the Valley of Toluca for the six defined time periods (from 1968 to 2006 ).

\begin{tabular}{|c|c|c|c|c|c|c|c|c|}
\hline & \multicolumn{8}{|c|}{ Energy consumption } \\
\hline & $C_{\text {sys }} 1968$ & $C_{\text {iniop }}$ & 1968-1975 & 1975-1981 & 1981-1987 & 1987-1993 & 1993-1999 & 1999-2006 \\
\hline$E C_{a v g w}$ & $5.6 \times 10^{4}$ & $5.1 \times 10^{4}$ & $1.85 \times 10^{5}$ & $1.97 \times 10^{5}$ & $1.98 \times 10^{5}$ & $2.35 \times 10^{5}$ & $2.6 \times 10^{5}$ & $2.78 \times 10^{5}$ \\
\hline SD & $9.4 \times 10^{4}$ & $8.8 \times 10^{4}$ & $2.62 \times 10^{5}$ & $2.78 \times 10^{5}$ & $2.90 \times 10^{5}$ & $3.46 \times 10^{5}$ & $3.87 \times 10^{5}$ & $4.24 \times 10^{5}$ \\
\hline$E C_{a v g}$ & 297 & 283 & 884 & 1064 & 1005 & 1186 & 1116 & 1062 \\
\hline SD & 234 & 231 & 473 & 620 & 686 & 735 & 767 & 842 \\
\hline$\sum C_{\text {varavg }}$ & & & $6.24 \times 10^{7}$ & $7.15 \times 10^{7}$ & $7.22 \times 10^{7}$ & $10.00 \times 10^{7}$ & $12.12 \times 10^{7}$ & $13.36 \times 10^{7}$ \\
\hline$\sum C_{\text {var }}$ & & & $4.37 \times 10^{8}$ & $4.29 \times 10^{8}$ & $4.33 \times 10^{8}$ & $6.02 \times 10^{8}$ & $7.27 \times 10^{8}$ & $9.35 \times 10^{8}$ \\
\hline$\sum C_{\text {varacum }}$ & & & $4.37 \times 10^{8}$ & $8.66 \times 10^{8}$ & $12.99 \times 10^{8}$ & $19.01 \times 10^{8}$ & $26.29 \times 10^{8}$ & $35.65 \times 10^{8}$ \\
\hline Incr\% & & & $58 \%$ & $81 \%$ & $83 \%$ & $154 \%$ & $207 \%$ & $239 \%$ \\
\hline
\end{tabular}

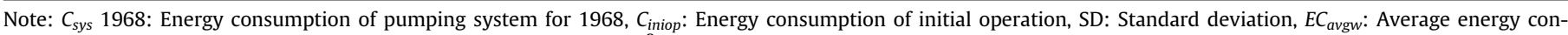

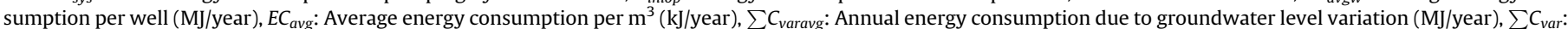

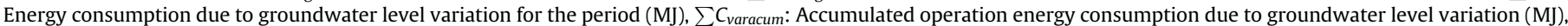
Incr\%: Increases of annual operation energetic cost due to groundwater level variation, $C_{\text {iniop }}$.

operational energy consumption $\sum C_{v a r}$ for each period to the previous one.

f. Increases in annual operational energy consumption due to variations in the groundwater level, (incr\%), dividing the difference between annual energy consumption due to groundwater level variations $\sum C_{\text {varavg }}$ and initial operational consumption $\sum C_{\text {iniop }}$ by the energy consumption of initial operations $\sum C_{\text {iniop }}$.

\subsection{Maps of energy consumption isopleths}

This process is possible due to the standardization of the extraction characteristics, which was achieved assuming a single type of pumping, leaving only the depth of groundwater level as a variable. Assumption is that, all the pumping wells extract the same volume and through the same pipe diameter, in addition to assuming that they have the same accessories and valves installed, in other words, the "type pump."

It is evident that the estimate of energy consumption is unreal, given the same volume of extraction for all the pumping wells. Therefore, in order to obtain the real energy consumption, the activity of each well was considered as a function of the extracted volume, using Eq. (6):

d.i. $=\left(V_{\text {ext }}-V_{\text {con }}\right)\left(86,400 Q_{T P}\right)^{-1}$

where d.i. is the number of inactive days of the type pump, $V_{\text {ext }}$ is the potential annual extraction volume for the type pump ( $\mathrm{m}^{3} / \mathrm{year}$ ), $V_{c o n}$ is the annual volume extracted from the well ( $\mathrm{m}^{3} /$ year), $Q_{T P}$ is the flow of the type pump $\left(\mathrm{m}^{3} \mathrm{~s}^{-1}\right)$ and 86,400 is the conversion factor from a flow rate of $\mathrm{m}^{3} \mathrm{~s}^{-1}$ to a daily flow rate $\left(\mathrm{m}^{3} /\right.$ day).

\section{Results and discussion}

The method proposed in this work and applied in the Valley of Toluca aquifer was conducted according to the diagram in Fig. 4. It encompasses 65 points based on data obtained from the piezometric monitoring network. Using the pumping well inventory, with data corresponding to 762 wells, a map of depth isopleths was generated to represent the same groundwater depth as in 1968 (Fig. 5). This map helped to calculate initial energy consumption. The next stage consisted of constructing maps to represent the same average annual decline for the periods 1968-1975, 19751981, 1981-1987, 1987-1993, 1993-1999 and 1999-2006. Fig. 6 shows the map of drawdown isopleths for the latest period. By locating each pumping well, it was possible to assign groundwater levels and average annual declines as a function of the isopleths and thereby estimate the energy consumption of intensive water extraction, as shown in the summary in Table 1.

Based on the data in Table 1, it is observed that:
1. Total energy consumption $C_{\text {sys }}$ for the entire aquifer was $4.26 \times 10^{7} \mathrm{MJ} /$ year and total energy consumption $C_{\text {iniop }}$ was $3.94 \times 10^{7} \mathrm{MJ} /$ year. In addition, the total energy consumption resulting from variations in the piezometric level $C_{v a r}$ was $6.24 \times 10^{7} \mathrm{MJ} /$ year during the first period (1968-1975) and increased to $13.3 \times 10^{7} \mathrm{MJ} /$ year during the last period (19992006).

2. The average annual energy consumption per well increased over time, in spite of pumping wells show that small energy savings during all periods.

3. The standard deviation of the average energy consumption per cubic meter has increased, highlighting the heterogeneity of the groundwater level variation over time and space.

4. The greatest increase in operational energy consumption due to variations in the groundwater level was observed during the period from 1987 to 1993 (particularly in the urban zone, as seen by piezometer PL-158 in Fig. 2), with a difference of 71\% with respect to the previous period. This increase could have caused by the synergy of multiple factors, including demographic and industrial growth (Mejía, 2003) as well as the water transfer to Mexico City reaching its maximum volume $\left(200 \mathrm{hm}^{3} /\right.$ year; Esteller and Diaz-Delgado, 2000).

5. During 1999-2006, the average operational energy consumption was $239 \%$ more than the initial operational consumption in

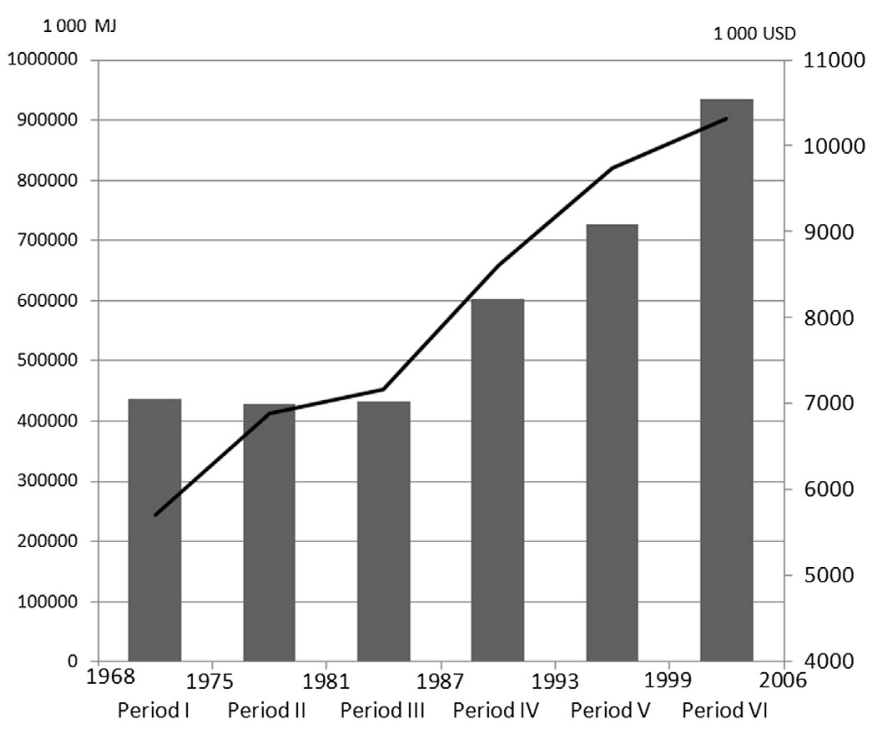

Energy consumption due to g.l. variation - Monetary costs in 2006

Fig. 7. Relation between energy consumption and monetary costs (value in 2006) accumulated by period. Own elaboration. Note: g.l. = groundwater level. 
1968 , the first year of the analysis, while values on the order of $1800 \%$ were reached in the central zone of the aquifer.

As mentioned at the beginning of this work, estimating energy consumption for aquifer exploitation makes it possible to define an equivalent value in monetary terms in order to determine an economic impact. For example, the economic impact caused by the groundwater level depletion between 2005 and 2006 was estimated based on the electric power production costs of USD $0.03 \times 10^{-3} / \mathrm{kJ}$ (Avila et al., 2005); this impact was USD 3,642,148, corresponding to an increase of $29.5 \%$ in the energy consumption cost of extraction per cubic meter (USD $0.03 / \mathrm{m}^{3}$ ).

Based on a time analysis (Fig. 7), it was also possible to show that the drawdown of groundwater levels causes large increases in energy consumption (as much as 36.3\% between 1987 and 1993) and monetary costs (as much as $21 \%$ between 1999 and 2006), even when the extracted volume of the wells remains constant. This cost may be passed on to the users if we consider that price elasticity is low, about $23 \%$ on average for agricultural use (estimated from Scott, 2011).

Fig. 8 shows, in energy and monetary terms, the proportion of operational consumption resulting from variations in the groundwater level, according to water use for the six time periods included in the study. It is important to highlighting that although a lower number of pumping wells was recorded for industrial use as compared to wells for domestic use, the energy consumption and resulting monetary cost to extract the volumes required by the industrial sector represent the highest percentage (48\%) of the total energy consumption. This is attributed to the rapid decline in groundwater levels in areas where the industrial water supply wells are located. In other words, $8 \%$ of groundwater extracted for industrial use requires $48 \%$ of the total energy consumption in this aquifer region.

On the other hand, the following characteristics were considered to generate the maps of energy consumption isopleths with the type pump:

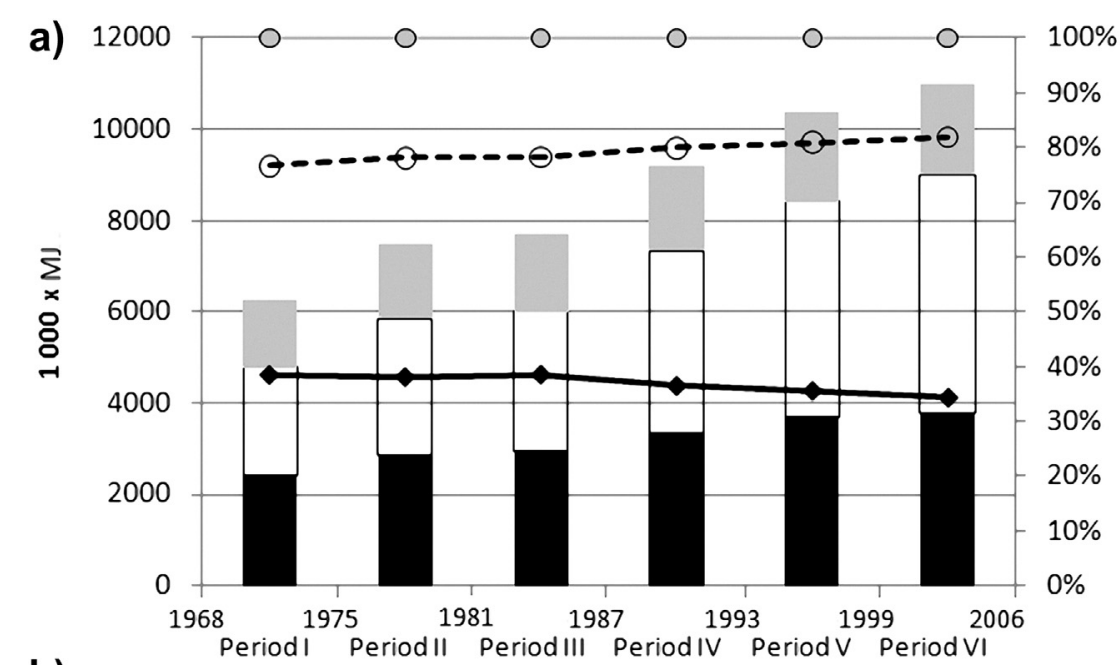

b)

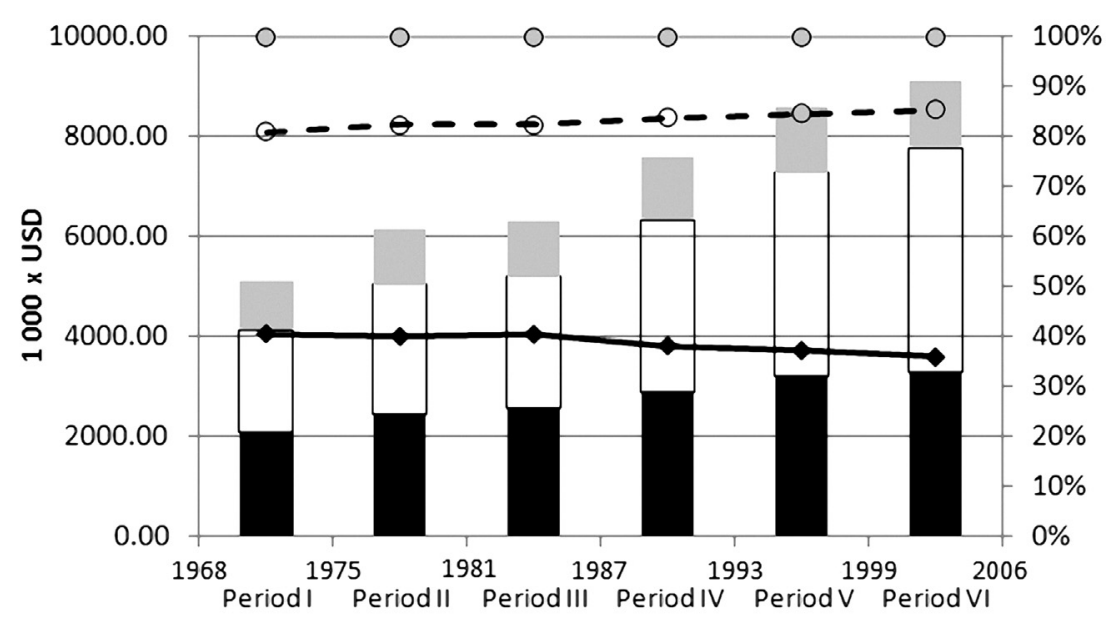

$\begin{array}{cl}\begin{array}{c}\text { Energy consumption/ } \\ \text { Monetary cost }\end{array} & \begin{array}{c}\text { Accumulated } \\ \text { percentaje }\end{array} \\ \text { AGRICULTURE } & -0 \text { AGRICULTURE } \\ \text { 口 INDUSTRIAL } & -\oslash-\text { INDUSTRIAL } \\ \text { - DOMESTIC USE } & - \text { DOMESTIC USE }\end{array}$

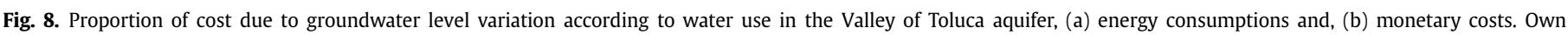
elaboration. 


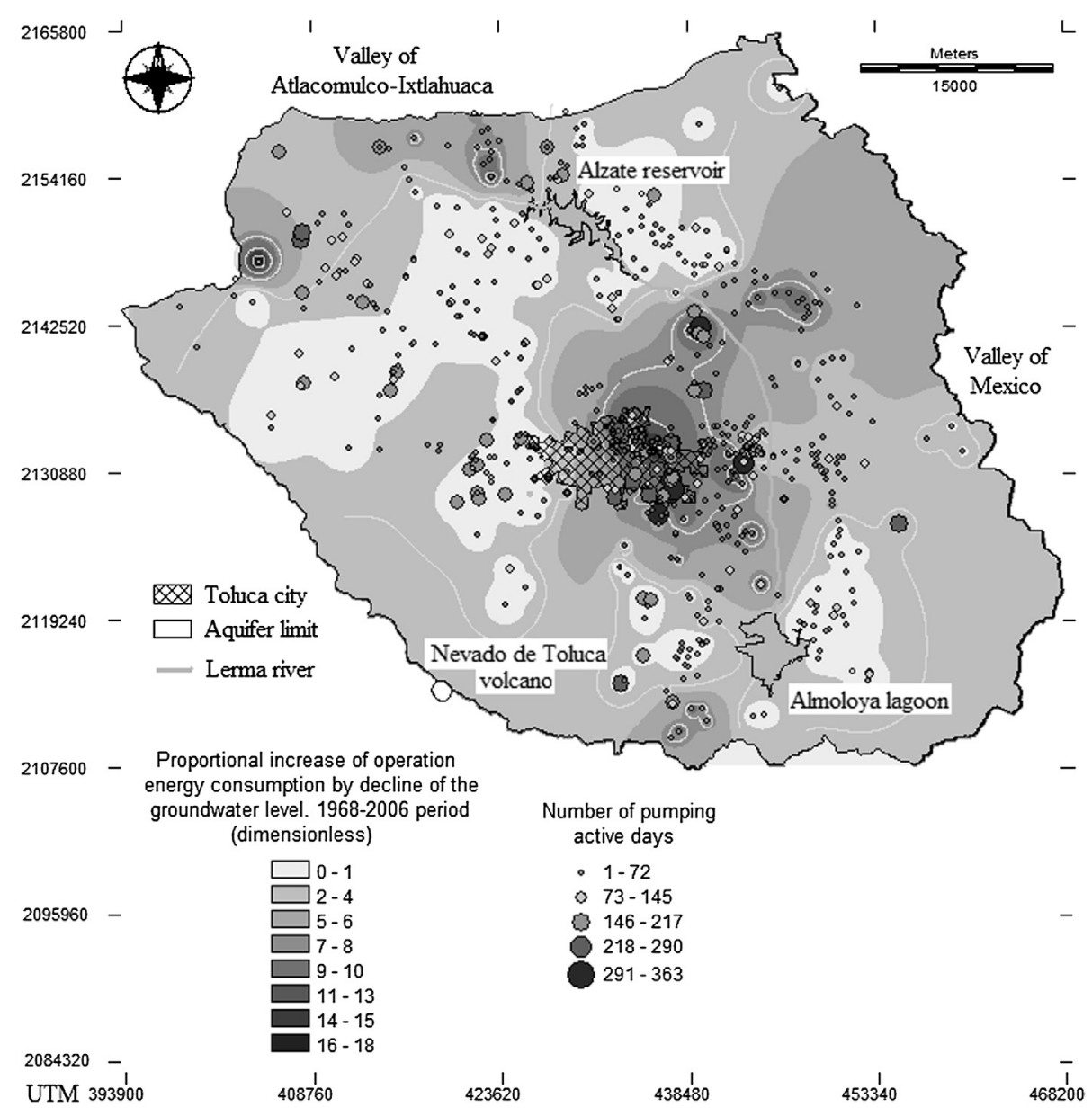

Fig. 9. Map of the proportional increase in energy consumption isopleths for the 1968-2006 period. Own elaboration.

1. An extraction flow of $42 \mathrm{~L} \mathrm{~s}^{-1}$, exceeding any flow from the pumping wells of the aquifer of the Valley of Toluca. A higher volume rate was used in order to ensure that all pumping wells have a maximum of 365 active days per year. Of the 762 wells that have records of extracted volume in the aquifer of the Valley of Toluca, the highest percentage (77\%) of pumps supply their annual volume during of less than 73 days of operation. On the other hand, less than $1 \%$ must operate up to 365 days in order to supply the annual volume required.

2. A nominal motor power of $50 \mathrm{HP}$, equal to $37.3 \mathrm{~kJ} / \mathrm{s}(37.3 \mathrm{~kW})$

3. The pump is a vertical type, with asynchronous velocity (used in deep wells) and a 3500 rpm motor.

4. The valves and accessories are the same for all the pumping systems considered.

For the period from 1968 to 2006, an interpolation of the inverse square of the distance-weighted average was used to generate the map for the proportional increase in operational energy consumption in the Valley of Toluca aquifer (Fig. 9). It can be seen that, in spite of the recharge of the piezometric level located in some of the zones during the last period (Fig. 6), an increase in energy consumption exists for the entire aquifer in the year 1968 due to the drawdown in piezometric levels during other periods. In addition, the area with the greatest susceptibility to a rapid increase ( $1800 \%$ with respect to 1968 ) in the energy consumption of extraction is the central area where the city of Toluca is located - the region where most pumping wells for urban and industrial use are located. Meanwhile, a trend towards energy savings exists in the western area of the aquifer, contrary to the perception that energy consumption has increased in the region. Therefore, areas with higher energy consumption not only represent the groundwater drawdown but also a high density of pumping wells with lower water extraction efficiency.

The estimates performed with this method provided minimal energy consumption since the information used corresponds to static levels in the piezometric network. Real energy consumption will increase according to differences in dynamic levels. This information is available for 574 of the 762 wells registered, but only for the year 2006. The greatest difference between static and dynamic levels is $96 \mathrm{~m}$, while the mean is $16 \mathrm{~m}$ with a standard deviation of $15 \mathrm{~m}$ and a range of $14.8-17.2 \mathrm{~m}$ at the confidence level of $95 \%$.

\section{Conclusions}

The proposed method has provided useful information which makes possible improve the groundwater management under a territorial approach. This information includes: estimating increased energy consumption from groundwater extraction in according with the operational conditions of exploitation and; identifying the areas which are more susceptible to increases in this energy consumption through the groundwater level monitoring.

Using the proposed method, it was possible to estimate the effect of intensive exploitation of the Valley of Toluca aquifer on the energy consumption of groundwater extraction. It was found that, for the year 2006, groundwater extraction required 2.39 times more energy than for the conditions observed 38 years earlier. In monetary terms, this corresponds to an increase of more than USD\$ 3 million/year, based on the cost of electric energy production in 2005. 
In addition, it was possible to identify the urban zone of Toluca as the most affected area in this regard, especially where extraction wells for industrial use are located, which represent $48 \%$ of the energy consumption of the entire aquifer (the volume of extracted volume associated to this energy consumption is equals with $37.27 \mathrm{hm}^{3} /$ year and represents the $8 \%$ of total). Nevertheless, zones still exist where the energy consumption of groundwater exploitation has not significantly increased with respect to the conditions observed in 1968 (in the northwest region of the aquifer).

This may indicate the relocation of extraction wells that consume greater amounts of energy as a result of technological and financial limitations, and even the direction of the growth of human settlements.

In addition, the energy consumption of the pumping equipment may represent a replacement cost if multiplied by the useful life of the equipment. Nonetheless, this methodology does not yet consider the energy consumption of other factors involved in the extraction of water, such as the perforation of new wells, increases in the depth of existing wells, human resources to operate the equipment and those involved in the structural logistics, and the energy required to monitor piezometric levels.

Thus, the results obtained with this method can be considered complementary to broader analyses of economic impacts or systems of power networks that contain these elements.

Nonetheless, the increase in energy consumption (as well as the corresponding decrease in the volume of available water) due to the drawdown of piezometric levels is an effect of the extraction of water and is ordinarily not regulated by operating entities due to a lack of information about how much water is extracted in a basin, as well as who is extracting it and from where. Therefore, a method that estimates this effect is useful as a tool for the control and management of groundwater resources.

This highlights the importance of identifying the causes of a drawdown in piezometric levels (such as an inadequate distribution of wells), how to measure it (through flow models and monitoring) and its management while achieving territorial planning.

By generalizing the characteristics of pumping wells, the equations used allow for estimating annual energy consumption based on records of extracted water volumes in the aquifer region as well as establishing the susceptibility of particular areas to energy cost increases resulting from variations in groundwater levels. In fact, the density and efficiency of the infrastructure installed in the region also reflect an increase in energy consumption isopleths, providing additional information about the evolution of aquifer levels for the purpose of groundwater management.

The maps of energy consumption according to groundwater extraction made it possible to include each pumping well regardless of the type of water used or the rate plan assigned to it. They are undoubtedly helpful to analyze the impacts of water extraction on the water supply and to easily communicate complex hydrogeological information to a broader audience.

\section{Appendix A. Supplementary material}

Supplementary material associated with this article can be found, in the online version, at http://dx.doi.org/10.1016/j.jenvman. 2013.06.042.

\section{References}

Avila, S., Muñoz, C., Jaramillo, L., Martinez, A., 2005. Un análisis del subsidio a la tarifa 09. Gaceta Ecológica 75, 65-76 (in Spanish).

Biswas, A.K., 2004. Opinion. From Mar del Plata to Kyoto: an analysis of global water policy dialogue. Global Environmental Change 14, 81-88.
Carrera-Hernández, J.J., Gaskin, S.J., 2007. The basin of Mexico aquifero system: regional groundwater level dynamics and database development. Hydrogeology Journal 15, 1577-1590.

Changming, L., Jingjie, Y., Kendy, E., 2001. Groundwater exploitation and its impact on the environment in the North China Plain. Water International 26 (2), 265-272.

CONAGUA, 2007. Estadísticas del Agua en México. Edición 2007. Secretaría de Medio Ambiente y Recursos Naturales, México D.F. (in Spanish).

Esteller, M.V., Díaz-Delgado, C., 2000. Las aguas subterráneas en una cuenca de altura: el Valle de Toluca. In: Antón, D., Díaz-Delgado, C. (Eds.), Sequía en un mundo de agua. Piriguazú/ CIRA, Costa Rica/México, p. 409 (in Spanish).

Esteller, M.V., Díaz-Delgado, C., 2002. Environmental effects of aquifer overexploitation: a case study in the Highlands of Mexico. Environmental Management 29 (2), 266-278.

Esteller, M.V., Expósito, J.L., Díaz-Delgado, Paredes, J., Fonseca, C.R., 2013. Explotación intensiva del acuífero del Valle de Toluca: Análisis de algunos efectos económicos-ambientales (in press). In: Fall, C. (Ed.), Avances en Ciencias del Agua. Universidad Autónoma del Estado de México (in Spanish).

Esteller, M.V., Rodríguez, R., Cardona, A., Padilla-Sánchez, L., 2011. Evaluation of hydrochemical changes due to intensive aquifer exploitation: case studies from Mexico. Environmental Monitoring and Assessment. http://dx.doi.org/10.1007/ s10661-011-2376-0.

Fonseca, C.R., Esteller, M.V., Díaz-Delgado, C., 2010. Energy cost of water extraction in an aquifer under intensive exploitation in the Mexican Highlands. In: 10th International Symposium on Stochastic Hydraulics. Québec, Canada.

Gupta, M., Srivastava, P.K., 2010. Integrating GIS and remote sensing for identification of groundwater potential zones in the hilly terrain of Pavagarh, Gujarat, India. Water International 35 (2), 233-245.

Harou, J.J., Lund, J.R., 2008. Ending groundwater overdraft in hydrologic-economic systems. Hydrogeology Journal 16, 1039-1055.

Herrera, M.E., Sanchez, J.L., 1994. Estratificación y recursos minerales del Estado de México. In: Memoria y mapas. Gobierno del Estado de México. Secretaría de Desarrollo Económico, México.

Hoque, M.H., Hoque, M.M., Ahmed, K.M., 2007. Declining groundwater level and aquifer dewatering in Dhaka metropolitan area, Bangladesh: causes and quantification. Hydrogeology Journal 15, 1523-1534.

Hsiao, C.T., Chang, L.C., 2002. Dynamic optimal groundwater management with inclusion of fixed costs. Water Resources Planning and Management 128 (1), 57-65.

INEGI, 2005. Sistema de consulta principales resultados por localidad 2005. Conteo de población y vivienda 2005 (accessed 08.12.08). http://www.inegi.org.mx (in Spanish).

IMTA, 2006. Censo de aprovechamientos en el acuífero Valle de Toluca. Secretaría de Medio Ambiente y Recursos Naturales, Mexico D.F. (in Spanish)

Kabwe, A.M., Fester, V.G., Slatte, P.T., 2010. Prediction of non-Newtonian head losses through diaphragm valves at different opening positions. Chemical Engineering Research and Design 88 (8), 959-970.

Kajenthira, A., Siddiqi, A., Díaz Anadon, L., 2012. A new case of promoting wastewater reuse in Saudi Arabia: bringing energy into the water equation. Journal of Environmental Management 102, 184-192.

Loustaunau, S., 2011. El aprovechamiento del agua subterránea en el uso público urbano y la sustentabilidad de los acuíferos. In: Memorias del VIII Congreso Nacional de Aguas Subterráneas, Querétaro, México. (in Spanish).

MacDonald, A.M., Ó Dochartaigh, B.É., Calow, R.C., Shalabi, Y., Selah, K., Merrett, S., 2009. Mapping groundwater development costs for the transboundary Western Aquifer Basin, Palestine/Israel. Hydrogeology Journal 17, 1579-1587.

Malik, R.P.S., 2002. Water-energy nexus in resources-poor economies: the Indian experience. International Journal of Water Resources Development 18, 47-58.

Martin, N., van de Giesen, N., 2005. Spatial distribution of groundwater production and development potential in the Volta river basin of Ghana and Burkina Faso. Water International 30 (2), 239-249.

Martínez, S.E., Escolero, O., Wolf, L., 2011. Total urban water cycle models in semiarid environments - quantitative scenario analysis at the area of San Luis Potosi, Mexico. Water Resources Management 25, 239-263.

Mejía, L.E., 2003. Situación del acuífero del Valle de Toluca. Ingeniando, CICEM 25 (6), 6-12 (in Spanish)

Molina, J.L., García Aróstegui, J.L., Benavente, J., Varela, C., de la Hera, A., López Geta, J.A. 2009. Aquifers overexploitation in SE Spain: a proposal for the integrated analysis of water management. Water Resources Management 23, 2737-2760.

Palacios-Vélez, O.L., Palacios-Vélez, E., Peña-Díaz, S., Gutiérrez-Carrillo, N., 2002. Escenarios para el aprovechamiento sustentable del acuífero del Valle de Querétaro. Agrociencia 36 (1), 1-10 (in Spanish).

Ramos, J.S., Ramos, H.M., 2009. Sustainable application of renewable sources in water pumping systems: optimized energy system configuration. Energy Policy 37, 633-643.

Salameh, E., 2008. Over-exploitation of groundwater resources and their environmental and socio-economic implications. The case of Jordan. Water International 33 (1), 55-68.

Scott, C.A., 2011. The water-energy-climate nexus: resources and policy outlook for aquifers in Mexico. Water Resources Research 47, W00L04. http://dx.doi.org/ 10.1029/2011WR010805.

Scott, C.A., Shah, T., 2004. Groundwater overdraft reduction through agricultural energy policy: insights from India and Mexico. Water Resources Development 20 (2), 149-164.

Sekar, I., Randhir, T.O., 2007. Policies for sustaining groundwater resources in India. Water International 32 (1), 697-709. 
Spiegel, M.R., Liu, J., 1999. Mathematical Handbook of Formulas and Tables. McGraw-Hill, p. 278.

Thi Hoang Duong, T., Adin, A., Jackman, D., van der Steen, P., Vairavamoorthy, K., 2011 Urban water management strategies based on a total urban water cycle model and energy aspects - case study for Tel Aviv. Urban Water Journal 8 (2), 103-118.

Venot, J.P., Molle, F., 2008. Groundwater depletion in the Jordan highlands: can pricing policies regulate irrigation water use? Water Resources Management 22, 1925-1941.

Wester, P., Hoogesteger, J., Vincent, L., 2009. Local IWRM organizations for groundwater regulation: the experiences of the aquifer management councils (COTAS) in Guanajuato, Mexico. Natural Resources Forum 33, 29-38.

Wester, P., Sandoval-Minero, R., Hoogesteger, J., 2011. Assessment of the development of aquifer management councils (COTAS) for sustainable groundwater management in Guanajuato, Mexico. Hydrogeology Journal 19, 889-899.

Yildirim, G., Singh, V.P., 2010. A MathCAD procedure for commercial pipeline hydraulic design considering local energy losses. Advances in Engineering Software 41 (3), 489-496.

Zacharias, I., Dimitriou, E., Koussouris, Th, 2003. Developing sustainable water management scenarios by using thorough hydrologic analysis and environmental criteria. Journal of Environmental Management 69, 401-412.

\section{Glossary}

The following symbols are used in this paper:

$C_{a c c}$ : energy consumption equivalent to head losses due to accessories and valves (kJ/year)

$C_{\text {motor: }}$ energy consumption equivalent to motor-pump system (kJ/year)

$C_{\text {iniop: }}$ : energy consumption of initial operation (kJ/year)

$C_{v a r}$ : energy consumption due to annual increase in groundwater depth (kJ/year)
$C_{\text {sys: }}$ : energy consumption equivalent to pumping system ( $\mathrm{kJ} / \mathrm{year}$ ) d.i.: inactive days of a type pump

$E C_{a v g}$ : average annual energy consumption per cubic meter of water extracted (kJ/year)

$E C_{\text {avgw: }}$ average annual energy consumption per well (MJ/year)

g: gravitational acceleration $\left(\mathrm{m} \mathrm{s}^{-2}\right)$

$Q_{T P}$ : type pump flow $\left(\mathrm{m}^{3} \mathrm{~s}^{-1}\right)$

$Q_{\text {extracted: }}$ extracted volume from a well $\left(\mathrm{m}^{3} \mathrm{~s}^{-1}\right)$

$Q_{\text {nom: }}$ : potential volume that could be extracted with the nominal power $\left(\mathrm{m}^{3} \mathrm{~s}^{-1}\right)$ $H$ : hydraulic head $(\mathrm{m})$

$h_{p}$ : average decline of groundwater level for a period (m/year)

incr\%: increase in annual energy consumption due to groundwater level variation (dimensionless)

$K$ : dimensionless coefficient that depends on type of accessory or valve, Reynolds number, and pipe roughness

Lps: liters per second

$n$ : number of years of a period

$P$ : power $\left(\mathrm{J} \mathrm{s}^{-1}\right)$

$P_{n}$ : motor nominal power $(\mathrm{kJ})$

Q: pumping rate or discharge $\left(\mathrm{m}^{3} \mathrm{~s}^{-1}\right)$

$Y_{Q}$ : yield of the extracted flow (dimensionless)

$v$ : velocity $\left(\mathrm{m} \mathrm{s}^{-1}\right)$

$V_{\text {con }}$ : annual extracted volume from a well $\left(\mathrm{m}^{3} /\right.$ year $)$

$V_{\text {ext }}$ : extraction potential annual volume of the type pump $\left(\mathrm{m}^{3} /\right.$ year $)$

$\gamma$ : specific water weight $\left(\mathrm{kg} \mathrm{m}^{-3}\right)$

$\eta$ : system overall efficiency (dimensionless)

$\sum C_{\text {varacum: }}$ : accumulated energy consumption due to groundwater level variation (MJ)

$\sum C_{\text {varavg: }}$ annual energy consumption due to groundwater level variation (MJ/year) 